\title{
Görme Engelli Bireylerin Depresif Belirtilerine Yönelik Psikodrama Temelli Grup Uygulaması
}

\section{A Psychodrama-Based Group Application Aimed at Depressive Symptoms of Sight-Disabled Individuals}

\section{Deniz ŞARLAK * Erdinç ÖZTÜRK ${ }^{* *}$}

Öz: Çalışma depresif belirtilere ve olumsuz duygulara sahip görme engelli bireylerin depresif belirtilerinin ve olumsuz duygularının azaltılmasında psikodrama temelli grup uygulamasının etkisinin incelenmesi amaciyla yapılmıştır. Araş̧ırmada, gerçek denemeli modellerden ön test-son test kontrol gruplu deneysel model uygulanmıştır. Sosyal medya aracilığılla ulaşılan 50 görme engelli bireye Beck Depresyon Ölçeği ve Pozitif ve Negatif Duygu Ölçeği uygulanmış olup depresif belirtilere ve olumsuz duygulara sahip 36 görme engelli birey çalışmaya alınmıştır. Tespit edilen görme engellilerden gönüllü olan 36 görme engelli bireyin, depresif belirti puan değerleri ve cinsiyet oranları dikkate alınarak 18 'i deney grubunda, 18 'i kontrol grubunda yer almıştır. Deney grubundaki görme engelli bireylerin \%55.6'sı kadın, \%50'si 26-29 yaş grubunda, \%44.4'ü evli, \%44.4'ü ortaokul mezunu, \%38.9'u bir işte çalışmaktadır. Psikodrama temelli grup uygulaması haftada 2 gün ve 3 saat süren 13 oturumdan oluşmaktadır. Kontrol grubuna deney grubundaki tüm oturumlar bittikten 4 hafta sonra psikodrama temelli grup uygulaması yapılmışır. Yapılan çalışma sonucunda deney grubundaki görme engelli bireylerin depresif belirtileri ve olumsuz duyguları azalmıştır. Psikodrama temelli grup uygulamasının son test ve ön test puanlarının ortalamaları arasında istatiksel olarak anlamlı bir fark elde edildiği belirlenmiştir. 4 hafta sonra yapılan izlem testinde kalıcilığın devam ettiği ve deney grubunda yer alan görme engelli bireylerde istenilen amaca ulaşıldığı görülmüş̧ür.

\section{Anahtar sözcükler: Psikodrama Temelli Grup Çalışması, Görme Engelli, Depresyon}

Abstract: This study was implemented for the purpose of examining the impact of a psychodrama-based group application which is performed to reduce depressive symptoms of sight-disabled individuals who have depressive symptoms and negative feelings and increase their positive feelings. Being among true experimental models; an experimental model with pretest-posttest control group was used in the study. Beck's Depression Scale and Positive and Negative Feeling Scale were applied to 50 sight-disabled individuals who were reached via social media and a total of 36 sight-disabled individuals who had depressive symptoms and negative feelings were detected. Among the sight-disabled individuals detected, 36 sight-disabled individuals who volunteered were separated into groups (18 experimental, 18 control) based on their depressive symptom scores and girl-boy ratio. $55.6 \%$ of the sight-disabled individuals are women, $50 \%$ are 26 years old, $44.4 \%$ are married, $44.4 \%$ are secondary school graduates and $38.9 \%$ are employed. The psychodrama-based group application consists of 13 sessions which take 2 days and 3 hours a week in the experimental group. The psychodrama-based group application was applied to the control group 4 weeks after all the sessions in the experimental group were completed. As a result of the study, it was determined that the psychodrama-based group application was useful for the development and change aimed at reducing depressive symptoms of sightdisabled individuals in the experimental group and increasing their positive feelings and there was a statistically significant difference between the pretest-posttest score averages. In the follow-up test which was performed 4 weeks later, it was seen that the permanence continued and the goal was achieved in the sight-disabled individuals in the experimental group.

Keywords: Psychodrama Group Therapy, Visual Impaired, Depression

\footnotetext{
* Dr. Öğr. Üyesi, Muğla Sıtkı Koçman Üniversitesi, Muğla. sarlakdeniz@gmail.com, https://orcid.org/0000-0001-6246-8301

** Prof. Dr., İstanbul Üniversitesi-Cerrahpaşa, Adli Tip Enstitüsü, İstanbul. erdincerdinc@hotmail.com, https://orcid.org/00000003-1553-2619
} 
Giriş

Dünya Sağlık Örgütü, engelliliği; bireyin sağlığının bozulması sonucu oluşan yetersizlikten dolayı, herhangi bir yeteneğinin normal sayılan bireylere göre kaybedilmesi veya azalması şeklinde belirtmektedir. Duyma, bedensel, zihinsel ve görme engellilik durumu bireyin günlük yaşamındaki aktiviteleri olumsuz yönde etkilemekte ve psikososyal sorunlara neden olmaktadır. 2011 yılında hazırlanan Dünya Sağlık Örgütü'nün Dünya Engellilik Raporu'nun sonuçlarına göre tüm dünyada yetişkinlerde engellilik oranının \%15.6 olduğu bildirilmektedir [Türkiye İstatistik Kurumu (TÜİK) 2013a]. Dünya nüfusunun hızla yaşlanması, savaşların devam etmesi ve kronik hastalıklardaki artış nedeni ile engellilik oranları her geçen gün artmaktadır. Türkiye'de yaklaşık 8.5 milyon kronik hasta ve engelli bireyler çevrelerindeki hareketliliklerini kısıtlayan çok sayıda engel ve uygun olmayan düzenlemeler nedeniyle toplumsal hayatta birçok sorunla karşılaşmaktadırlar (TÜIK 2013b). Nüfus ve Konut Araştırması (2011) verilerine göre; toplumda yer alan bireylerin \%6.9'unun en az bir engele sahip olduğu tespit edilmiştir. Başbakanlık Özürlüler İdaresi Başkanlığı'nca yürütülen Özürlüler Araştırması'nda (2002) engellilik altı kısımda; zihinsel, görme, işitme, ortopedik, dil ve konuşma engelli ve süreğen hastalık şeklinde yer almıştır.

Görme engelli bireyler hiç görmeyen ve az gören bireyler olarak ayrılmaktadır. Görme alanındaki yetersizlik ise yasal tanımlama ve eğitsel tanımlama olarak iki bölümde incelenmektedir. Yasal tanımlama; görme engelli bireyin tüm tedavisi yapılmasına rağmen görme gücünün 10'da 1 ya da çok daha az olan bireyleri belirtmektedir. Eğitsel tanımlama ise; görme engeli bulunan bireyin eğitiminde dokunsal ve işitsel materyalleri kullanıyor olmasını kapsamaktadır (Kocaömer 2012; Kurulay 2014). Dünya Sağlık Örgütü (2001) verilerine göre dünyada 45 milyon, Türkiye'de Boğaziçi Üniversitesi Görme Engelliler Teknoloji Laboratuvarı'nın yaptığı çalışmada yaklaşık 400 bin görme engelli birey bulunmaktadır (Öztürk 2011). Bu 400 bin görme engelli bireyin; \%28'inin bir gözü görmekte, \%21'inin iki gözü çok az görmekte, $\% 0.6$ 's1 ise hiç görememektedir.

Sayıları azımsanmayacak olan görme engelli bireylerin gündelik yaşamında karşı karşıya kaldıkları sorunlar oldukça fazladır. Taylor (1999) engelliliği; engelli bireye diğer insanların verdiği tepki olarak tanımlamaktadır. Sonradan veya doğuştan kazanılmış engellilik, içinde bulunulan toplumun engelli bireye bakış açısı ile şekillenmekte ve bu da her toplumda farklılıklar göstermektedir. Engellilik görme engelli bireyin sadece kendisi ile sınırlandırılmaz. Çünkü görme engelli birey günlük yaşamında toplum içinde sürekli olarak farklı engellerle karşılaşmaktadır (Erdoğan 2017). Toplumun en büyük azınlık gruplarından biri olan görme engelli bireylerde damgalanma oldukça fazladır. Görme engelli birey olması nedeniyle toplumsal alanda çok fazla sorun yaşamaktadırlar. En temel haklarından yoksun kalmakta; ön yargı, toplumdan dışlanma, ayrımcılık ve ekonomik sorunlar yaşamaktadırlar (Ekenci 2015). Bir başka devam eden sorun ise görme engelli bireylerin işe girme konusunda ayrımcılık yaşamaları ya da iş sektöründe ön yargılardan dolayı vasıfsız işlerde çalıştırılmalarıdır (Çağlar 2011). Üretkenliklerini kullanamayan, başkalarına bağımlı olarak yaşamak zorunda kalan görme engelli bireyler her geçen gün kendilerini zayıf, güçsüz ve yetersiz olarak görmekte, toplumla bütünleşememekte ve toplumdan uzaklaşmaya başlamaktadır. Kendisini toplumun bir parçası olarak hissedemeyen görme engelli bireyler yalnızlaşmakta ve içe kapanmaktadırlar (Burcu 2011). Yalnızlık ve umutsuzluk duygularını yaşayan görme engelli bireyler bir süre sonra depresif belirtilerle karşılaşmakta ve bu bireylerin çaresizlikleri artmaktadır. Bu çalışmada öncelikle görme engelli bireylerin depresif belirtileri ele alınmış ve bu depresif belirtilerden uzaklaşabilmeleri için psikodrama temelli grup uygulaması yapılmıştır. 


\section{Depresyon ve Belirtileri}

Ruhsal bozukluklar arasında yer alan depresyon; özellikle 30'lu yaşlarda başlayan ve dezavantajlı grupları (engelli, yaşı, kadın) önemli ölçüde etkileyen ciddi bir halk sağlığı sorunudur. Depresyon, toplumda yaygın olarak görülen, bireyin içinde bulunduğu durumdan dolayı kendini mutsuz ve yorgun hissettiği, günlük işlere karşı isteksizlik, üzüntü ve yaşamdan zevk alamama durumudur (Sütçügil \& Özmenler 2007). Birey karamsar düşünceler içerisinde; geçmişi ve geleceği ile ilgili birçok şeyi olumsuz olarak değerlendirmektedir. Geçmişte yaşadığı olaylardan dolayı kendisini suçlu ve geçmişin gölgesinde gelecek için umutsuz hissetmektedir. Olumsuz duyguları yoğun hisseden birey bir süre sonra yaşamın anlamsız olduğunu düşünmekte, sosyal iletişim performansında düşüş yaşamakta ve iş/okul ortamında başarısızlıklarla karşılaşmaktadır (Karamustafalığl \& Yumrukçal 2011). Öztürk (2001) bireyin depresyon halini; yoğun üzüntü duygu durumu içinde konuşma, düşünme, hareketlerde durgunluk, güçsüzlük, değersizlik, karamsar duygular ile fizyolojik işlevlerde bozulma olarak tanımlar. Öztürk (2004) depresif belirtiler yaşayan bireylerde bilişsel, sosyal ve biyolojik (kalıtsal, nörobiyolojik, nörokimyasal) sistemlerde birtakım sapmalar ve bu sistemlerin birbiri ile yakından ilişkili olduğunu ifade etmektedir. Çelikkol (1999) ise depresif bireylerin üzüntü hali, kolay sinirlenme, suçluluk hissi, ümitsizlik ve intihar eğilimleri gibi psikolojik yakınmalarının olduğunu belirtmektedir. Depresyon tanısı; ilgi ve istekte azalma, depresif duygu durumu; üzüntü ve çökkünlük hali, uykusuzluk veya aşırı uyuma, iştahta artma veya azalma, psikomotor becerilerde yavaşlama, enerjide düşüklük, dikkatte dağılma, suçluluk ve değersizlik gibi düşünceler, tekrarlayan intihar veya ölüm düşüncesi belirtilerinin art arda 15 gün boyunca hemen her gün en az beşinin görülmesi durumunda konulmaktadır (Amerikan Psikiyatri Birliği 2013).

Beck'in (1972) geliştirmiş olduğu depresyonda bilişsel bozukluklar modeline göre belirleyici neden olarak bilişler ele alınmaktadır. Beck (1972), bilişsel yapıların depresif belirtilerin psikolojik alt yapısına etken olduğunu belirterek, bunları üç bölüme ayırmış ve bilişsel üçlü tanımını yapmıştır. Bilişsel üçlü; bireyin kendisine, çevresine ve geleceğine yönelik olumsuz düşüncelerini içermektedir.

Dünya Sağlık Örgütü'ne göre depresyonun en başta gelen nedenleri arasında engellilik yer almaktadır. Depresyon her yıl Amerika'da 17 milyondan fazla bireyi etkilemektedir. Bu etkilenen bireylerin çoğunluğunu engelli bireyler oluşturmaktadır. Ruh sağlığı ve görme kaybı ile ilgili çalışmalarda, görme engelli bireylerin görme kayıplarından dolayı depresyon tanısı aldıkları ve görme kaybının depresif belirtilerle ilişkili olduğu görülmektedir (Rees et al. 2009; 2013; Cosh et al. 2019). Tournier (2008) çalışmasında nüfusun yaşlanması ile birlikte, yaşlı yetişkinler arasında en yaygın üçüncü fiziksel bozulmanın görme bozukluğu olduğunu ve bununla birlikte depresif belirtilerin görüldügünü saptamıştır. Görme engelli yaşlı bireylerin yaşam kalitesi ve depresif belirtileri arasında pozitif yönde bir ilişki bulunmuştur (Casten 2002; Lamoureux 2009). Geri dönüşü olmayan görme engelli yetişkinlerin psikolojik uyumunun sistematik meta analizinin yapıldığı çalışmada 4 veri tabanı (PubMed, EBSCO, Cochrane Library ve Science Direct) kullanılarak 1946 ve 2014 yılları arasında yayınlanmış toplam 3948 çalışmadan 52 uygun çalışma seçilmiştir. Çalışmaların büyük çoğunluğu görme kaybı olanların yüksek düzeyde depresif belirtiler yaşadıklarını ve ruhsal sağlıklarının olumsuz yönde etkilendiğini ve bu etkilerin zaman içinde kalma eğiliminde olduğunu göstermektedir (Senra et al. 2015).

\section{Psikodrama ve Özellikleri}

Moreno tarafından geliştirilen psikodrama, grup psikoterapisi tekniğidir. Hellencedeki Pyskhe (ruh) ve Drama (eylem-işlem) sözcüklerinden oluşmaktadır. Psikodrama, danışanların, dramatizasyon ve rol oynama ile cesaretlendirildikleri grup psikoterapisi yöntemidir. Psikoterapötik ve sosyoterapötik bir eylem yöntemi olan psikodrama uygulamasında bireyler sorunlarını sözlü 
olarak ifade etmek yerine dramatize ederler. Geçmişte kalan belli bir olaya ilişkin anılar, sonuçlanmamış süreçler, rüyalar, kişiyi gelecekte karşılaşılacak risklere hazırlayan kurgular, şimdi ve burada ile ilgili ruhsal süreçlerin prova edilmemiş ifadeleri gibi durumları içeren pek çok sahne canlandırılmaktadır. Bu sahneler ya gerçek hayatta yaşanan olaylardan alıntılardır ya da içsel, ruhsal süreçlerin dışa vurumlarıdır. Sahneleme işleminde diğer grup üyeleri ve cansız nesneler de rol alabilmektedirler (Schützenberger-Ancelin 1995).

Bir başka deyişle psikodramanın temel amacı Moreno'ya göre, bireylerin spontanlıklarını ve yaratıcılıklarını geliştirmelerine firsat sağlamaktır. Spontanlık ve yaratıcılık sosyometri ve psikodramanın temel taşları arasında sayılmaktadır. Psikodramada sahnelenen oyunlar süresince bireylerde bir değişim gerçekleşmektedir. Bu gelişimin en temelini doğaçlama (spontanlık) oluşturmaktadır (Özbek \& Leutz 1987; Altınay 2000; Dökmen 2013). Psikodrama sahnesi bireylerin duygularını fark etmelerini, sözle ifade edebilmelerini ve beraberinde baskı altında tuttukları spontanlıklarını da arttırmaktadır. Spontanlığı artan birey daha yaratıcı ve üretken olabilmektedir. İnsanın doğasında var olan yaratıcılığın bastırılması, ortaya çıkmaması durumunda birtakım ruhsal sorunlar görülmektedir (Moreno 1939; Özbek \& Leutz 1987; Dökmen 2013). Psikodramada kullanılan 1sınma oyunları ve teknikleri depresif belirtileri olan görme engelli bireylerin sağaltımında işlevsel olduğu kadar, olası sorunlarına da önleyici bir yardım sunmaktadır. Psikodramada bireyler, eşleme, ayna ve rol değiştirme temel tekniklerini kullanarak geçmişteki travmatik olaylarını, geleceğe yönelik umut ve korkularını şimdiki zamana aktarmakta ve çözümlemektedirler. Bu şekilde bireyler günlük hayatta çeşitli baskılar yüzünden dışa vuramadıkları istek ve duygularını, spontan olarak oyunda, psikodrama sahnesinde açığa vurarak duygularını boşaltmakta böylece ruhsal ferahlığa ulaşmaktadırlar (Karp et al. 2013).

Psikodramada yer alan grup üyeleri, kendilerine ait ruhsal sorunlarını canlandırarak etkileşimde bulunmaktadırlar. Duygu ve heyecanla yüklü geçmiş yaşantıları, çatışmaları dramaya dökerek "şimdi ve burada" olma duygusunu yeniden yaşatması psikodramanın katartik işlevini ortaya çıkarmaktadır. Psikodramanın üç temel işlevi; duygusal boşalım, gerçeği test etme ve alternatif düşünceler geliştirmedir (Blatner 2002). Psikodramada birçok 1sınma tekniği bulunmakta olup en çok eşleme, rol değiştirme ve ayna teknikleri kullanılmaktadır. Bunların yanı sıra; kendini takdim, boş sandalye ve iç konuşmalar gibi teknikler de klasik teknikler arasında yer almaktadır. Psikodrama oturumları; 1sınma, oyun, işlemleme, paylaşım (rol paylaşımı ve özdeşim geri bildirimi) evrelerinden oluşmaktadır. Psikodrama grup uygulamasında kullanılan araçlar; oyunların gerçekleştiği sahne, grubun yöneticisi, başoyuncu (protagonist), başoyuncuya yardım eden oyuncular ve grubun izleyicisi üyelerdir (Kellerman,1992).

Psikodramanın etkileri incelendiğinde yurt dışı ve ülke içinde yapılmış olan çalışmalarda; şiddet gören kadınlar, yaşlı bireyler, işitme engelli kız öğrenciler, lise ve üniversite öğrencileri çalışma grubunda yer almıştır. Bu gruplarda bağımlılık, aleksitimi, yaşam doyumu, sınav kaygısı, tükenmişlik, psikolojik iyi oluş, travma, sosyal uyum, saldırganlık, depresif belirtiler, umutsuzluk ve intihar eğilimleri konuları ele alınmıştır (Somov 2008; Doğan 2010; 2012; Albayrak 2013; Karataş 2014; Özbaş 2014; Doğmuş-Ulusoy 2015; Parkan 2015; Bal \& Şener 2015; Şarlak \& Öztürk 2017; Göveç \& Başgül 2017; Şener 2018).

Sonuç olarak, görme engelli bireylere psikodrama uygulamasının yapıldığı çalışmalar olmadığ1 gözlenmiştir. İncelenen çalışmalarda sadece görme engelli bireyin depresif belirtiler yaşadığı belirtilmekte ve herhangi bir müdahale yapılmamıştır (Rees et al. 2013). Bu çalışmada psikodrama temelli grup uygulamasında kullanılan teknikler ile toplumdan kendini izole eden görme engelli bireylerin depresif belirtilerini ve olumsuz duygularını azaltmak amaçlanmıştır. 


\section{Yöntem}

Çalışmanın bu bölümünde araştırmanın modeli, çalışma grubu, psikodrama temelli grup uygulaması oturumları, veri toplama araçları ve verilerin değerlendirilmesi üzerinde durulmuştur.

Araştırma Modeli: Araştırmada, psikodrama temelli grup uygulamasının görme engelli bireylerin depresif belirtilerinin azaltılmasını amaçlayan gerçek denemeli modellerden "Ön testson test kontrol gruplu deneysel model" kullanılmıştır. Katılımcılar, deney uygulama işleminin öncesi ve sonrasında bağımlı değişkenle ilgili olarak ölçülmüştür (Büyüköztürk 2007). Araştırmanın bağımsız değişkeni, depresif belirtileri önlemeye yönelik hazırlanan psikodrama temelli grup çalışmasıdır. Araştırmanın bağımlı değişkeni, görme engelli bireylerin depresif belirtileridir. Kontrol değişkenleri ise; bu bireylerin cinsiyeti, yaşı, medeni durumu, sosyo-ekonomik düzeyi, geçmişte psikiyatrik bir tedavi alıp almadığıdır.

Tablo 1. Araştırmada Kullanılan Ön Test- Son Test Kontrol Gruplu Deneysel Desen

\begin{tabular}{|c|c|c|c|c|}
\hline Grup & Ön test & İşlem & Son test & İzlem \\
\hline Deney & $\begin{array}{l}\text { Kişisel Bilgi Formu } \\
\text { Beck Depresyon Ölçeği } \\
\text { Pozitif ve Negatif } \\
\text { Duygu Ölçeği }\end{array}$ & $\begin{array}{l}\text { Psikodrama } \\
\text { Temelli Grup } \\
\text { Uygulaması }\end{array}$ & $\begin{array}{l}\text { Beck Depresyon Ölçeği } \\
\text { Pozitif ve Negatif } \\
\text { Duygu Ölçeği }\end{array}$ & $\begin{array}{l}\text { Beck Depresyon Ölçeği } \\
\text { Pozitif ve Negatif Duygu } \\
\text { Ölçeği }\end{array}$ \\
\hline Kontrol & $\begin{array}{l}\text { Kişisel Bilgi Formu } \\
\text { Beck Depresyon Ölçeği } \\
\text { Pozitif ve Negatif } \\
\text { Duygu Ölçeği }\end{array}$ & & $\begin{array}{l}\text { Beck Depresyon Ölçeği } \\
\text { Pozitif ve Negatif } \\
\text { Duygu Ölçeği }\end{array}$ & $\begin{array}{l}\text { Beck Depresyon Ölçeği } \\
\text { Pozitif ve Negatif Duygu } \\
\text { Ölçeği }\end{array}$ \\
\hline
\end{tabular}

Araştırmanın deseni Tablo 1'de verilmiştir. Araştırma kontrol ve deney gruplarında depresif belirtileri hafif düzeyde ve olumsuz duyguları yüksek olan görme engelli bireylerle yapılmıştır. Deney grubunda yer alan görme engelli bireylere psikodrama eğitimi almış grup yürütücüsü (ayrıca co-terapist eşliğinde) tarafindan psikodrama 1sınma oyunlarının yer aldığı yarı yapılandırılmış psikodrama temelli grup oturumları uygulanmıştır. Kontrol grubuna ise bu süreçte herhangi bir uygulama yapılmamıştır. Deney grubunun çalışması bittikten sonra kontrol grubuna psikodrama temelli grup çalışması yapılmıştır.

\section{Örneklem}

Araştırmanın yürütüldüğü gruba sosyal medya aracılığıyla ulaşılmıştır. 50 görme engelli birey gönüllü olarak başvurmuştur. Katılımcılar ile ön görüşme yapılmıştır. Bu görüşmede çalışmanın amacı, oturumların süresi, çalışmanın planlandığı tarih, üye sayısı, kurallar ve psikodrama temelli grup çalışmasının gönüllük ilkesine dayalı olduğu belirtilmiş ve sözlü onam alınmıştır. Deney ve kontrol gruplarının oluşturulması için 50 görme engelli bireye Beck Depresyon Ölçeği ve Pozitif ve Negatif Duygu Ölçeği uygulanmıştır. Bu uygulanan ölçeklerden depresif belirtileri kesme puanlarına göre hafif düzeyde (11-16 puan) ve olumsuz duygu durumu (36 ve üzeri puan) yüksek olan 36 görme engelli birey belirlenmiştir. Daha önce psikiyatrik tanı almış ve tedavi uygulanmış, depresyon puanı yüksek ve ilaç kullanan görme engelli bireyler çalışma dışında tutulmuştur. Gruplara yerleştirme işlemi yapılırken ölçeklerden alınan puanlar ve cinsiyetler göz önünde bulundurulmuştur. Deney grubunda 18 görme engelli birey ve kontrol grubunda 18 görme engelli birey olmak üzere toplamda 36 görme engelli birey çalışmaya alınmıştır. Kontrol grubunda yer alan katılımcılara çalışmanın uygun olan bir zamanda yapılacağ 1 ve kendileri ile iletişime geçileceği konusunda bilgi verilmiştir. 
Tablo 2. Araştırmaya Katılan Deney ve Kontrol Grubundaki Görme Engelli Bireylerin SosyoDemografik Özellikleri

\begin{tabular}{|c|c|c|c|c|c|}
\hline \multirow{2}{*}{ Grup } & & \multicolumn{2}{|c|}{ Deney } & \multicolumn{2}{|c|}{ Kontrol } \\
\hline & & $\mathbf{n}$ & $\%$ & $\mathbf{n}$ & $\%$ \\
\hline \multirow{2}{*}{ Cinsiyet } & Kadın & 10 & 55.6 & 10 & 55.6 \\
\hline & Erkek & 8 & 45.4 & 8 & 45.4 \\
\hline \multirow{3}{*}{ Yaş } & 18 - 21 yaş & 5 & 27.8 & 5 & 27.8 \\
\hline & 22 - 25 yaş & 4 & 22.2 & 5 & 27.8 \\
\hline & 26 - 29 yaş & 9 & 50.0 & 8 & 44.4 \\
\hline \multirow{2}{*}{ Medeni Durum } & Bekar & 8 & 44.4 & 8 & 44.4 \\
\hline & Evli & 10 & 55.6 & 10 & 55.6 \\
\hline \multirow{3}{*}{ Eğitim } & İlkokul & 4 & 22.2 & 3 & 16.7 \\
\hline & Ortaokul & 8 & 44.4 & 7 & 38.9 \\
\hline & Lise & 6 & 33.3 & 8 & 44.4 \\
\hline \multirow{2}{*}{ Çalışma Durumu } & Çalışan & 7 & 38.9 & 5 & 27.8 \\
\hline & Çalışmayan & 11 & 61.1 & 13 & 72.2 \\
\hline
\end{tabular}

Tablo 2'de araştırmaya katılan deney ve kontrol grubundaki görme engelli bireyler sosyodemografik özelliklerine göre incelendiğinde; deney grubundakilerin \%55.6's1 kadın, \%50'si 26-29 yaş grubunda, \%44.4'ü evli, \%44.4'ü ortaokul mezunu, \%38.9'u bir iște çalıșmaktadır. Kontrol grubunda yer alan görme engelli bireylerin demografik özellikleri: \%55.6'sı kadın, \%44.4'ü 26-29 yaş grubunda, \%44.4'ü evli, \%44.4'ü lise mezunu, \%27.8’i bir işte çalışmaktadır.

\section{Araştırma Ölçme Araçları}

Bu çalışmada, katılımcılara Kişisel Bilgi Formu, Beck Depresyon Ölçeği ve Pozitif ve Negatif Duygu Ölçekleri uygulanmıştır.

\section{Kişisel Bilgi Formu}

Çalışmaya katılan görme engelli bireylere uygulanan kişisel bilgi formunda; cinsiyet, yaş, eğitim, medeni durum, çalışma hali ve görme engellilik düzeyi sorulmuştur.

\section{Beck Depresyon Ölçeği}

Beck Depresyon Ölçeği Beck (1961) tarafından geliştirilmiş ve Türkçe uyarlaması Hisli (1989) tarafından yapılmıştır. Ölçeğin temel amacı, bireydeki depresif belirtilerin düzeyini sayısal olarak göstermektir. Ölçekteki maddeler depresyonun belirtilerine ilişkindir. Ölçekte yer alan toplam 21 maddede, depresif belirtilere ilişkin örüntüler dört seçenek halinde sunulmakta en düşükten en yükseğe doğru (0-3) sıralanmaktadır. Ölçekten alınan toplam puanlar alınabilecek olan en yüksek puan altmış üç (63), en düşük puan ise sıfırdır (0). Türkiye'de bu ölçek kullanılarak yapılan çalışmalarda; 0-10 puan normal, 11-16 puan hafif düzey, 17-20 puan sınırda klinik, 21-30 puan orta düzey, 31-40 puan ciddi düzey, 40 puan ve üzeri çok ciddi düzey yaşadığını göstermektedir. Ölçeğin kesme puanı 17 olarak belirtilmiştir (Hisli 1989). Ölçeğin geçerlilik ve güvenilirlik çalışmasında Cronbach alfa katsayısı 0.80, araştırmada ise, depresyon ölçeğinin Cronbach's alpha değeri .86 olarak bulunmuştur.

\section{Pozitif ve Negatif Duygu Ölçeği}

Pozitif ve Negatif Duygu Ölçeği Watson, Clark ve Tellegen (1988) tarafından geliştirilmiş ve 20 maddeden (10 olumlu; 10 olumsuz) oluşmaktadır. Ölçekte olumlu duyguların bulunduğu boyut duygusal iyi oluş halini, olumsuz duyguların bulunduğu boyut ise duygusal stres halini içermektedir. Türkiye'de Gençöz (2000) tarafından geçerlilik ve güvenilirlik çalışması yapılmıştır. 
Cronbach alfa değerleri olumsuz duygular için .83, olumlu duygular için .86'tır. Yapılan çalışmada ise olumsuz duygular için .76, olumlu duygular için .82'dir. Ölçekte yer alan boyutlarda puanların yüksek olması, olumlu veya olumsuz duyguların şiddetli yaşandığını göstermektedir.

\section{Araştırmanın Uygulanması}

Yaşantısal bir grup ortamında yürütülen oturumlar, deney gruplarında toplamda 13 oturum ve haftada 2 kez yapılmıştır. Oturumların süresi 3 saat sürmüştür. Ana hedef olumlu duyguların arttırılması ve depresif belirtilerin azalması çerçevesinde kalınarak oturumlar psikodrama temelli grup çalışması ile yürütülmüştür. Her oturum için planlanan hedef ve etkinlikler olmakla beraber, katılımcıların o andaki ihtiyaç ve çalışmak istedikleri konular da dikkate alınmıştır. İlk görüşmede yapılan ölçek uygulaması, çalışma gruplarının ön testleri olarak kabul edilmiştir. Etik kurul izni alınan çalışma için katılımcılardan sözlü onam alınmıştır. Araştırmanın son testleri ise oturumların bitiminden bir hafta sonra uygulanmıştır. Kontrol grubuna tüm çalışmalar bittikten sonra psikodrama temelli grup çalışması yapılmıştır. Psikodrama temelli grup oturumları katılımcıların rahatlıkla paylaşımda bulunabilecekleri bir salonda yapılmıştır. Her oturum başlangıcında katılımcılara bir önceki oturumla ilgili eklemek istedikleri bir konu olup olmadığı sorulmuş ve yeni oturuma başlanmıştır.

\section{Oturumlar}

Deney grubundaki görme engelli bireylere psikodrama temelli grup çalışması, 3 saat süren oturumlar șeklinde 13 oturumda yürütülmüștür. Her oturum protogonist merkezli veya grup oyunu şeklinde gerçekleştirilmiştir. Paylaşım aşaması iki aşamalı şekilde; rol paylaşımı ve özdeşim geri bildirimi olarak yapılmıştır.

1. Oturum: Psikodrama temelli grup çalışması hakkında bilgi verilmiştir. Grup üyelerinin tanışması için 1sınma oyunu yapılmıştır. Grup kuralları oluşturulmuştur. Oturum grup paylaşımı ile sonlandırılmıştır.

2. Oturum: Bir önceki oturumun özetlemesi yapılmıştır. Isınma oyunu (ormanda piknik organizasyonu) ile görme engelli bireyler arasında grup dinamiğinin oluşturulması, bu bireylerin duygularını ve düşüncelerini ifade etmeleri sağlanmıştır. Rol paylaşımı ve özdeşim geri bildirimi ile oturum sonlandırılmıştır.

3. Oturum: Bir önceki oturumun özetlemesi yapılmıştır. "Depresif belirtiler" hakkında bilgi verilmiş ve grup oyunu oynanmıştır. Rol paylaşımı ve özdeşim geri bildirimi ile oturum sonlandırılmıştır.

4. Oturum: Bir önceki oturumun özetlemesi yapılmıştır. Depresyonun bilişsel üçlü modeline dayanarak grup üyelerinin "kendileri ile ilgili olumsuz düşünceleri" üzerinde çalışılmıştır. Protogonist oyunu ile devam eden oturum rol paylaşımı ve özdeşim geri bildirimi ile sonlandırılmıştır.

5. Oturum: Bir önceki oturumun özetlemesi yapılmıştır. Depresyonun bilişsel üçlü modeline dayanarak "bireyin çevresine ve geleceğine yönelik olumsuz düşünceleri" üzerinde çalışılmıştır. Protogonist oyunu ile devam eden oturum rol paylaşımı ve özdeşim geri bildirimi ile sonlandırılmıştır.

6. Oturum: Bir önceki oturumun özetlemesi yapılmıştır. Depresif belirtilerin oluşmasında etkili olan "ekonomik faktörler" üzerinde durulmuştur. Ekonomik faktörler ile ilgili grup oyunu (iş başvurusu için görüşme) oynanmıştır. Rol paylaşımı ve özdeşim geri bildirimi ile oturum sonlandırılmıştır.

7. Oturum: Bir önceki oturumun özetlemesi yapılmıştır. Depresif belirtilerin oluşmasında etkili olan "çevresel faktörler" üzerinde durulmuştur. Çevresel faktörler ile ilgili grup oyunu oynanmıştır. Rol paylaşımı ve özdeşim geri bildirimi ile oturum 
sonlandırılmıştır.

8. Oturum: Bir önceki oturumun özetlemesi yapılmıştır. Depresif belirtilerin oluşmasında etkili olan "damgalanma" üzerinde durulmuştur. Damgalanma ile ilgili grup oyunu oynanmıştır. Grup oyunu protogonist oyununa dönüşmüştür. Rol paylaşımı ve özdeşim geri bildirimi ile oturum sonlandırılmıştır.

9. Oturum: Bir önceki oturumun özetlemesi yapılmıştır. Depresif belirtilerden biri olan "uyku sorunu” üzerinde durulmuştur. Uyku sorunu ile ilgili grup oyunu oynanmıştır. Grup oyunu protogonist oyununa dönüşmüş̧ür. Rol paylaşımı ve özdeşim geri bildirimi ile oturum sonlandırılmıştır.

10. Oturum: Bir önceki oturumun özetlemesi yapılmıştır. Depresif belirtilerden biri olan "yeme sorunu" üzerinde durulmuştur. Yeme sorunu ile ilgili grup oyunu oynanmıştır. Grup oyunu protogonist oyununa dönüşmüş̧ür. Rol paylaşımı ve özdeşim geri bildirimi ile oturum sonlandırılmıştır.

11. Oturum: Bir önceki oturumun özetlemesi yapılmıştır. Depresif belirtilerden biri olan "sosyal ilişskilerde bozulma" sorunu üzerinde durulmuştur. Sosyal ilişkilerde bozulma ile ilgili grup oyunu oynanmıştır. Rol paylaşımı ve özdeşim geri bildirimi ile oturum sonlandırılmıştır.

12. Oturum: Bir önceki oturumun özetlemesi yapılmıştır. "Depresif belirtiler ile başa çıkma yolları" üzerinde durulmuştur. Başa çıkma yollarını konu olan grup oyunu oynanmıştır. Rol paylaşımı ve özdeşim geri bildirimi ile oturum sonlandırılmıştır.

13. Oturum: Bir önceki oturumun özetlemesi yapılmıştır. Grup oyunu (grup heykeli, veda ve teşekkür) ile tüm oturumların değerlendirilmesi yapılmıştır. Rol paylaşımı ve özdeşim geri bildirimi ile oturum sonlandırılmıştır.

\section{Verilerin İstatistiksel Analizi}

Ölçme araçları ile toplanan verilerin analizinde SPSS (The Statistical Packet for The Social Sciences) 22.0 paket programından yararlanılmıştır. Görme engelli bireylerin tanıtıcı değişkenlerinin betimlenmesinde; frekans (f) ve yüzde (\%) kullanılmıştır. Deney ve kontrol grubu görme engelli bireylerin ön-testlerinin ve her iki grubun ön-test son-test karşılaştırmaları ile araştırmada kalıcılığına ilişkin son test ve izlem testi puanları arasındaki karşılaş̧ırmalarda bağımlı gruplar için t testi analizi uygulanmıştır. Aynı katılımcılardan deney öncesinde ve deney sonrasında ölçümler toplandığı, seçkisiz olarak atama yapıldığı ve gözlemler aynı sayıda veri değerlerine sahip olduğu için $\mathrm{t}$ testi analizi yapılmıştır.

\section{Bulgular}

Araştırmanın bulguları bu bölümde ele alınmıştır. Deney ve kontrol grubundaki görme engelli bireylerin depresyon, pozitif ve negatif duygularının ön test puan ortalamalarına ait veriler karşılaştırılmıştır. Daha sonra psikodrama temelli grup çalışmasının etkisini test etmek amacıyla kontrol ve deney grubu katılımcılarının depresyon, pozitif ve negatif duygularının son test puan ortalamaları karşılaştııılmıştır. Deney ve kontrol grubunun depresyon, pozitif ve negatif duygularının puan ortalamaları her iki grup için ön test - son test karşılaştırmaları $t$ testi ile ayrı ayrı sınanmıştır. Programın kalıcılığını test etmek için psikodrama temelli grup çalışması uygulandıktan 4 hafta sonra deney grubu katılımcılarına izlem ölçümü yapılmış ve son-test puanları ile karşılaştırılmıştır. 
Tablo 3. Deney ve Kontrol Grubundaki Görme Engelli Bireylerin Depresyon, Pozitif ve Negatif Duygu Ölçeklerinden Aldıkları Ön Test Puanlarına İlişkin n, $\bar{x}$, Ss ve t Değerleri

\begin{tabular}{lllllll}
\hline Ölçekler & Grup & $\mathbf{n}$ & $\overline{\boldsymbol{x}}$ & Ss & t & p \\
\hline Beck Depresyon & Deney & 18 & 14.20 & 1.81 & & \\
& Kontrol & 18 & 13.87 & 1.79 & 2.30 & .14 \\
Pozitif Duygu & Deney & 18 & 14.28 & 1.44 & & \\
& Kontrol & 18 & 14.98 & 1.58 & .35 & .86 \\
Negatif Duygu & Deney & 18 & 30.15 & 8.74 & & \\
& Kontrol & 18 & 31.01 & 7.69 & 1.52 & .40 \\
\hline$n=36$, (Deney=18, Kontrol $n=18), p>.05$ & & & &
\end{tabular}

Tablo 3 incelendiğinde deney ve kontrol grubundaki görme engelli bireylerin depresyon ön test puanının $\bar{x}=14.20 \pm 1.81$, kontrol grubunun puanının $\bar{x}=13.87 \pm 1.79$ olduğu görülmektedir. Buna göre deney ve kontrol grubundaki katılımcıların ön test puan ortalamaları arasında istatistiksel olarak anlamlı bir fark bulunmamıştır $(t=2.30 ; \mathrm{p}>.05)$. Deney ve kontrol grubundaki görme engelli bireylerin pozitif duygu ön test puanının $\bar{x}=14.28 \pm 1.44$, kontrol grubunun puanının $\bar{x}=14.98 \pm 1.58$ olduğu görülmektedir. Buna göre deney ve kontrol grubundaki katılımciların ön test puan ortalamaları arasında istatistiksel olarak anlamlı bir fark bulunmamıştır $(\mathrm{t}=.35 ; \mathrm{p}>.05)$. Deney ve kontrol grubundaki görme engelli bireylerin negatif duygu ön test puanının $\bar{x}=30.15 \pm 8.74$, kontrol grubunun puanının $\bar{x}=31.01 \pm 7.69$ olduğu görülmektedir. Buna göre deney ve kontrol grubundaki katılımcıların ön test puan ortalamaları arasında istatistiksel olarak anlamlı bir fark bulunmamıştır $(\mathrm{t}=1.52 ; \mathrm{p}>.05)$.

Tablo 4. Deney ve Kontrol Grubundaki Görme Engelli Bireylerin Depresyon, Pozitif ve Negatif Duygu Ölçeklerinden Aldıkları Son Test Puanlarına İlişkin $n, \bar{x}$, Ss ve t Değerleri

\begin{tabular}{llccccc}
\hline Ölçekler & Grup & $\mathbf{n}$ & $\overline{\boldsymbol{x}}$ & Ss & t & p \\
\hline Beck Depresyon & Deney & 18 & 7.80 & 2.12 & & \\
& Kontrol & 18 & 12.64 & 1.14 & 1.42 & .00 \\
Pozitif Duygu & Deney & 18 & 38.21 & 2.32 & & \\
& Kontrol & 18 & 13.27 & 1.21 & .28 & .00 \\
Negatif Duygu & Deney & 18 & 12.10 & 5.25 & & \\
& Kontrol & 18 & 30.12 & 6.52 & 1.24 & .00 \\
\hline
\end{tabular}

$n=36$, (Deney=18, Kontrol $n=18$ ), $p<.05$

Tablo 4 incelendiğinde deney ve kontrol grubundaki görme engelli bireylerin depresyon son test puanının $\bar{x}=7.80 \pm 2.12$, kontrol grubunun puanının $\bar{x}=12.64 \pm 1.14$ olduğu görülmektedir. Buna göre deney ve kontrol grubundaki katılımciların son test puan ortalamaları arasında istatistiksel olarak anlamlı bir fark saptanmıştır $(\mathrm{t}=1.42 ; \mathrm{p}<.05)$. Deney ve kontrol grubundaki görme engelli bireylerin pozitif duygu son test puanının $\bar{x}=38.21 \pm 2.32$, kontrol grubunun puanının $\bar{x}=13.27 \pm 1.21$ olduğu görülmektedir. Buna göre deney ve kontrol grubundaki katılımcıların son 
test puan ortalamaları arasında istatistiksel olarak anlamlı bir fark tespit edilmiştir $(\mathrm{t}=.28$; $\mathrm{p}<.05$ ). Deney ve kontrol grubundaki görme engelli bireylerin negatif duygu son test puanının $\bar{x}=12.10 \pm 5.25$, kontrol grubunun puanının $\bar{x}=30.12 \pm 6.52$ olduğu görülmektedir. Buna göre deney ve kontrol grubundaki katılımcıların son test puan ortalamaları arasında istatistiksel olarak anlamlı bir fark bulunmuştur. $(\mathrm{t}=1.24 ; \mathrm{p}<.05)$.

Tablo 5. Deney Grubundaki Görme Engelli Bireylerin Depresyon, Pozitif ve Negatif Duygu Ölçeklerinden Aldıkları Ön Test-Son Test Puanlarına İlişkin $n, \bar{x}$, Ss ve t Değerleri

\begin{tabular}{llcccccc}
\hline Ölçekler & Grup & $\mathbf{n}$ & $\overline{\boldsymbol{x}}$ & Ss & $\mathbf{t}$ & $\mathbf{p}$ \\
\hline Beck Depresyon & Ön test & 18 & 14.20 & 1.81 & & \\
& Son test & 18 & 7.80 & 2.12 & 1.78 & .00 & \\
Pozitif Duygu & Ön test & 18 & 14.28 & 1.44 & & \\
& Son test & 18 & 38.21 & 2.32 & 1.22 & .00 \\
Negatif Duygu & Ön test & 18 & 30.15 & 8.74 & & \\
& Son test & 18 & 12.10 & 5.25 & 1.24 & .00 \\
& & & & & & &
\end{tabular}

(Deney $n=18), p<.05$

Tablo 5 incelendiğinde deney grubundaki görme engelli bireylerin depresyon ön test puanının $\bar{x}=14.20 \pm 1.81$, son test puanının $\bar{x}=7.80 \pm 2.12$ olduğu görülmektedir. Deney grubundaki görme engelli bireylerin depresyon ön test-son test puan ortalamaları arasında istatistiksel olarak anlamlı bir fark tespit edilmiştir $(\mathrm{t}=1.78 ; \mathrm{p}<.05)$. Deney grubundaki görme engelli bireylerin pozitif duygu alt boyutundan aldıkları ön test puanının $\bar{x}=14.28 \pm 1.44$, son test puanının $\bar{x}=38.21 \pm 2.32$ olduğu saptanmıştır. Buna göre deney grubundaki görme engelli bireylerin pozitif duygu alt boyutundan aldıkları ön test ve son test puan ortalamaları arasında istatistiksel olarak anlamlı bir fark saptanmıştır $(\mathrm{t}=1.22 ; \mathrm{p}<.05)$. Deney grubundaki görme engelli bireylerin negatif duygu alt boyutundan aldıkları ön test puanının $\bar{x}=30.15 \pm 8.74$, son test puanının $\bar{x}=12.10 \pm 1.24$ olduğu saptanmıştır. Buna göre deney grubundaki görme engelli bireylerin negatif duygu alt boyutu ön test ile son test puan ortalamaları arasında istatistiksel olarak anlamlı bir fark tespit edilmiştir $(\mathrm{t}=1.24 ; \mathrm{p}<.05)$.

Tablo 6. Deney Grubundaki Görme Engelli Bireylerin Depresyon, Pozitif ve Negatif Duygu Ölçeklerinden Aldıkları Son Test - İzlem Testi Puanlarına İlişkin n, $\overline{\boldsymbol{x}}$, Ss ve t Değerleri

\begin{tabular}{llccccc}
\hline Ölçekler & Grup & $\mathbf{n}$ & $\overline{\boldsymbol{x}}$ & Ss & t & $\mathbf{p}$ \\
\hline Beck Depresyon & Son test & 18 & 7.80 & 2.12 & & \\
& İzlem & 18 & 6.75 & 1.87 & 4.37 & .00 \\
& Son test & 18 & 38.12 & 2.32 & & \\
Pozitif Duygu & İzlem & 18 & 41.52 & 5.65 & 5.56 & .00 \\
& Son test & 18 & 12.10 & 5.25 & & \\
Negatif Duygu & İzlem & 18 & 10.25 & 4.28 & 6.53 & .00 \\
& & & & & & \\
\hline
\end{tabular}

(Deney $n=18), p<.05$ 
Tablo 6 incelendiğinde deney grubundaki görme engelli bireylerin depresyon ölçeğinden aldıkları son test puanının $\bar{x}=7.80 \pm 2.12$, izlem test puanının $\bar{x}=6.75 \pm 1.87$ olduğu görülmektedir. Deney grubundaki görme engelli bireylerin depresyon ölçeğinden aldıkları son test ve izlem testi puan ortalamaları arasında istatistiksel olarak anlamlı bir fark tespit edilmiştir $(\mathrm{t}=4.37$; $\mathrm{p}<.05$ ). Deney grubundaki görme engelli bireylerin pozitif duygu alt boyutundan aldıkları son test puanının $\bar{x}=38.21 \pm 2.32$, izlem testi puanının $\bar{x}=41.52 \pm 5.65$ olduğu saptanmıştır. Buna göre deney grubundaki görme engelli bireylerin pozitif duygu alt boyutundan aldıkları son test puanı ve izlem testi puan ortalamaları arasında istatistiksel olarak anlamlı bir fark saptanmıştır $(\mathrm{t}=5.56 ; \mathrm{p}<.05)$. Deney grubundaki görme engelli bireylerin negatif duygu alt boyutundan aldıkları son test puanının $\bar{x}=12.10 \pm 1.24$, izlem testi puanının $\bar{x}=10.25 \pm 4.28$ olduğu saptanmıştır. Buna göre deney grubundaki görme engelli bireylerin negatif duygu alt boyutundan aldıkları son-test puanı ile izlem testi puan ortalamaları arasında istatistiksel olarak anlamlı bir fark tespit edilmiştir $(\mathrm{t}=6.53 ; \mathrm{p}<.05)$.

\section{Sonuç}

Çalışma depresif belirtilere ve olumsuz duygulara sahip görme engelli bireylerin depresif belirtilerinin ve olumsuz duygularının azaltılması için uygulanan psikodrama temelli grup çalışmasının etkisini incelemek amacıyla yapılmıştır. Bu amaç doğrultusunda sosyal medya arac1lığıyla ulaşılan 50 görme engelli bireye Beck Depresyon Ölçeği ve Pozitif ve Negatif Duygu ölçeği uygulanmıştır. Çalışmaya gönüllü olan 36 görme engelli birey depresif belirti puan değerleri ve cinsiyet oranlarına dikkat edilerek çalışma gruplarına yerleştirilmiştir. Psikodrama temelli grup çalışması deney grubunda hafta 2 gün ve 3 saat süren 13 oturum olarak devam etmiştir. Kontrol grubuna deney grubundaki tüm oturumlar bittikten 4 hafta sonra psikodrama temelli grup çalışması yapılmıştır. Grup yöneticisi her bir oturumu genel amaçlar doğrultusunda planlamış ve oturum sırasında grup üyelerinin ihtiyaçlarına da dikkat etmiştir. Oturumlarda özellikle depresif belirtiler, bunların nedenleri, depresyonun bilişsel üçlüsü ve depresif belirtilerle başa çıkma yolları üzerinde durulmuştur.

Çalışmanın ilk bulgularından olan çalışma gruplarındaki (deney ve kontrol) katılımcıların ölçeklerden aldıkları ön test puan ortalamaları arasında istatistiksel olarak anlamlı bir fark bulunmamıştır. Bu sonuçlara göre deney ve kontrol grubu görme engellilerin aynı evrenden alındıkları, depresif belirtiler, olumlu ve olumsuz duygular açısından birbirlerine benzedikleri söylenebilir. Deney ve kontrol grubundaki görme engelli bireylerin depresif belirtileri hafif ve olumsuz duyguları yüksek düzeyde tespit edilmiştir. Rees et al. (2013) çalışmasında görme engelli bireylerin depresif belirtilere sahip olduğu belirtilmektedir. Bu, çalışmamızın bulgusunu destekler niteliktedir. Görme engelli bireylerin yaşadıkları eğitimsel, sosyal ve ekonomik sorunlar psikolojilerini olumsuz yönde etkilemektedir. Engelli birey olarak yaşama devam edebilmelerinin oldukça güç olduğunu belirten çalışmalar vardır (Luftig \& Muthert 2005).

Çalışmada deney ve kontrol grubundaki katılımcıların son test puan ortalamaları arasında istatistiksel olarak anlamlı bir fark saptanmıştır. Çalışma sonuçlarına göre psikodrama temelli grup çalışmasının görme engelli bireylerin depresif belirti ve olumsuz duygularını azaltmada istatistiksel olarak anlamlı bir etkiye sahip olduğu söylenebilir. Hamamcı'nın (2006) psikodrama çalışmasında da benzer sonuçlar bulunmuştur.

$\mathrm{Bu}$ sonucu destekleyen diğer bulgu ise; deney grubundaki görme engelli bireylerin depresif belirtilerinin ve olumsuz duygularının ön test-son test puan ortalamaları arasında istatistiksel olarak anlamlı bir farkın olmasıdır. Bunların yanı sıra psikodrama temelli grup çalışmasının oturumları bittikten 4 hafta sonra yapılan izlem testi araştırmanın etkinliğini ortaya koymaktadır. Deney grubundaki görme engelli bireylerin depresif belirti düzeyleri son test ve izlem testi puan ortalamaları arasında istatistiksel olarak anlamlı bir fark tespit edilmiştir. Çalışmada kontrol 
grubunun olması ve izlem ölçümlerinin yapılması çalışmayı güçlü kılmaktadır.

Ülkemizde engelli bireyler üzerine çalışmaların yapıldığ 1 ancak görme engelli bireylerin içinde yer aldığ çalışmaların sayısının az olduğu görülmektedir. Bu nedenle çalışma grubuna görme engelli bireyler alınmıştır. Bir diğer göze çarpan husus ise görme engelli bireylerde yap1lan çalışmalarda herhangi bir müdahale tekniğinin uygulanmamış olmasıdır. Genelde görme engelli bireylerin kullandıkları eğitim materyalleri, benlik saygısı, damgalanma, öfke ifade tarzları, sosyal kaygı, toplumsal yaşama katılım gibi konuların ele alındığı belirlenmiştir. Depresif belirtileri azaltmaya yönelik görme engelli bireylerde bilinçli farkındalık temelli bilişsel terapi programı uygulanmıştır (Demir 2015). Bunun yanı sıra literatür taramasında görme engelli bireylerin depresif belirtilerine yönelik uygulanan psikodrama grup çalışmasına rastlanmamıştır. Bu da çalışmayı özgün kılmaktadır. Yurt dışı literatüründe de benzer sonuçlar karşımıza çıkmaktadır. Psikodrama her ne kadar bazı çalışmalarda kullanılsa da benzer çalışmaya ulaşılamamıştır. MS hastalarında depresif belirtileri azaltmaya yönelik psikodrama çalışması yapılmıştır. Hastaların depresif belirtileri azalmıştır (Dehnavi et al. 2015). Bu araştırmanın bulguları da, mevcut araştırmamızın bulgularını destekler niteliktedir. Yapılan çalışma sonucunda deney grubundaki görme engelli bireylerin depresif belirtilerinin ve olumsuz duygularının azalması yönündeki gelişim ve değişim psikodrama temelli grup çalışmasının oldukça faydalı olduğunu göstermektedir. Elde edilen sonuçlara göre görme engelli bireyler grup çalışmasından faydalanabilmiş ve deney grubunda istenilen amaca ulaşılmıştır.

Her çalışmada olduğu gibi bu çalışmanın da bazı sınırlılıkları bulunmaktadır. Psikodrama temelli grup çalışmasına ilişkin alan yazınında benzer çalışmaya rastlanmadığı için çalışma sonuçları kıyaslanamamıştır. Ayrıca farklı içeriğe sahip yöntemlerle yapılmış çalışmaların olmaması nedeniyle bulgular karşılaştırılamamıştır. Çünkü görme engelli bireylere müdahale teknikleri ile yapılan sadece bir çalışma tespit edilmiş̧tir (Demir 2015). Araştırma kapsamında ulaşılan görme engelli bireylerin genel görme engelli bireylerin nüfusunu temsil etmesi beklenmemiştir. $\mathrm{Bu}$ nedenle, katılımcılardan elde edilen bulguların sınırlılıklar çerçevesinde değerlendirilmesi gerekmektedir. Araştırma; araştırma sürecine gönüllü olarak katılan görme engelli bireylere ait verilerle sınırlıdır. İleride yapılacak çalışmalarda oturum süresi daha uzun tutabilir. Bu çalışmada tek izlem ölçümü alınmıştır. Planlanan diğer çalışmalarda izlem ölçümleri artırabilir.

Sınırlılıkları olmasına rağmen; psikodrama temelli grup çalışmasının görme engelli bireylerin depresif belirtilerini ve olumsuz duygularını azaltmada etkin olduğu görülmüştür. Araştırmanın sonuçlarından yola çıkılarak şu önerileri sıralayabiliriz; görme engelli bireylerin içinde yer aldığı çalışmalar arttırılabilir. Bu çalışmada depresif belirtiler ve duygular ele alınmıştır. Gelecekteki çalışmalarda stres, stresle başa çıkma yolları ve damgalanma konuları üzerinde durulabilir. Kontrol grubuna bir başka müdahale tekniği uygulanarak sonuçlar karşılaştırılabilir. Böylece psikodrama temelli grup uygulamasının etkinliği bir kez daha gözden geçirilmiş olur.

\section{Yazarın Notu}

Bu çalışma 06-10 Haziran 2018 tarihleri arasında Hollanda/Amsterdam'da düzenlenen 22. Dünya Psikoterapi Kongresi’nde sözlü bildiri olarak sunulmuştur. 


\section{KAYNAKÇA}

Aile ve Sosyal Politikalar Bakanlığı (2001). Dünya Engellilik Raporu. Ankara 2001.

Albayrak G. (2013). Psiko-eğitim Programı ile Psikodramanın Üniversite Öğrencilerinin Psikolojik İyi Oluşlarına Etkisinin Karşılaştırılması. Yayımlanmamış Yüksek Lisans Tezi. Mersin Üniversitesi, Mersin 2013.

Altınay D. (2000). Psikodrama Grup Psikoterapisi El Kitabı. Yaşama Dair Çok Şey. Herkesin Öyküsüne Sahnede Yer Var. İstanbul 2000.

Amerikan Psikiyatri Birliği (2013). Ruhsal Bozuklukların Tanısal ve Sayımsal Elkitabı. (DSM-5) Tanı Ölçütleri Başvuru Elkitabı. Ed. E. Köroğlu. Ankara 2013.

Bal P. N. \& Şener Ö. (2015). "Psikosomatik Hastalıkların İyileştirilmesinde Psikodramanın Etkisi”. Uluslararası Ĕgitim Bilimleri Dergisi 5 (2015) 310-323.

Beck A. T. (1961). “An Inventory for Measuring Depression”. Arch Gen Psychiatry 1 (1961) 561-571.

Beck A. T. (1972). “Cognition, Anxiety, and Psychophysiological Disorders”. Ed. C. Spielberger, Anxiety: Current Trends in Theory and Research. New York 1972.

Blatner A. (2002). Psikodramanın Temelleri. Ankara 2002.

Burcu E. (2011). “Türkiye'deki Engelli Bireylere İlişkin Kültürel Tanımlamalar: Ankara Örneği”. Hacettepe Üniversitesi Edebiyat Fakültesi Dergisi 28/1 (2011) 37-54.

Büyüköztürk Ș. (2007). Deneysel Desenler Öntest-Sontest Kontrol Grubu Desen ve Veri Analizi. Ankara 2007.

Casten R. J., Rovner B. \& Edmonds S. E. (2002). "The Impact of Depression in Older Adults with AgeRelated Macular Degeneration”. Journal of Visual Impairment \& Blindness 96/6 (2002) 399-406.

Cosh S., Carriere I., Nael V., Tzourio C., Delcourt C. \& Helmer C. (2019). "Sense-Cog Consortium. The Association of Vision Loss and Dimensions of Depression Over 12 Years in Older Adults: Findings From The Three City Study”. Journal Affect Disorders 15 (243) (2019) 477-484.

Çağlar S. (2011). "Engelli Hakları Sözleşmesi’nde Ayrımcılık Yasağı ve Türkiye'nin Uyum Sorunu”. TBB Dergisi (2011).

Çelikkol A. (1999). Ruh Hastalıklarından Korunma. İstanbul 1999.

Dehnavi S., Hashemi S. F. \& Mohammadi A. Z. (2015). "Effectiveness of Psychodrama on Reducing Depression Among Multiple Sclerosis Patients”. International Journal of Behavioral Sciences 10/1 (2015) 32-35.

Demir V. (2015). “Görme Engellilerde Depresif Belirtilere Yönelik Bilinçli Farkındalık Temelli Bilişsel Terapi Programının Etkililiği”. Nesne Dergisi 3/6 (2015) 77-93.

Doğan T. (2010). "The Effects of Psychodrama on Young Adults' Attachment Styles". The Arts in Psychotherapy 37 (2010) 112-119.

Doğan T. (2012). "Sağlıklı Duygusal İlişkiler Geliştirmede Psikodramanın Rolü: Bir Olgu Sunumu”. Türk Psikolojik Danışma ve Rehberlik Dergisi 4 (37) (2012) 49-60.

Doğmuş-Ulusoy Y. (2015). Psikodrama Teknikleri ile Bütünleştirilmiş Etkileşim Grubu Uygulamasının Karşılıklı Bağımlılık Üzerindeki Etkisi. Yayımlanmamış Doktora Tezi. Çukurova Üniversitesi, Adana 2015.

Dökmen Ü. (2013). Sosyometri ve Psikodrama. İstanbul 2013.

Ekenci M. T. (2015). “2012 Türkiye Sağlık Araştırması’nın Engelliliğe İlişkin Yaygınlık Ölçümü Açısından İncelenmesi”. Sosyal Politika Çalışmaları Dergisi 35/2 (2015).

Erdoğan O. (2017). "İnsan Hakları Bağlamında Engelli Kadınların Sosyo-Ekonomik Sorunları: Trabzon İli Örneği”. Hak Işs Uluslararası Emek ve Toplum Dergisi 6/14 (2017) 89-114.

Gençöz T. (2000). "Pozitif ve Negatif Duygu Ölçeği: Geçerlik ve Güvenirlik Çalışması”. Türk Psikoloji Dergisi 15/46 (2011) 19-26.

Göveç N. \& Başgül N. T. (2017). "Psikodrama ve Bilişsel Davranışçı Terapi Yöntemi ile Grup Çalışmasının Sınav Kaygısı Üzerindeki Etkileri”. Bilişsel Davranışçı Psikoterapi ve Araştırmalar Dergisi 6/1 (2017) 22-30.

Hamamc1 Z. (2006). "Integrating Psychodrama and Cognitive Behavioral Therapy to Treat Moderate Depression”. The Arts in Psychotherapy 33/3 2006 199-207.

Hisli N. (1989). "Beck Depresyon Envanteri'nin Üniversite Öğrencileri İçin Geçerliği, Güvenirliği”. Türk Psikoloji Dergisi 7/23 (1989) 3-13.

Karamustafalığlu O. \& Yumrukçal H. (2011). “Depresyon ve Anksiyete Bozuklukları”. Şişli Etfal Hastanesi Tip Bülteni 45/2 (2011) 65-74.

Karataş Z. (2014). "Psikodrama Uygulamasının Üniversite Öğrencilerinin Öznel İyi Oluş ve Umutsuzlukları Üzerindeki Etkisi”. Eğitim ve Bilim 9/173 (2014) 118-128.

Karp M., Holmes P. \& Tauvon K. B. (2013). Psikodrama Rehberi. Ankara 2013. 
Kocaömer Y. (2012). “Engelliler Tarihi”. Kaynak: http://engelsizerisim.com/yazilar.php?oku=1\&id=334

Kurulay H. (2014). "İnsan Hakları Aynasında Engelliler. Eğitime Bakış”. Ĕ̆itim-Öğretim ve Bilim Araştırma Dergisi 31/10 (2014) 61-66.

Lamoureux E. L., Fenwick E., Moore K., Klaic M., Borschmann K. \& Hill K. (2009). “Impact of the Severity of Distance and Near-Vision İmpairment on Depression and Vision-Specific Quality of Life in Older People Living in Residential Care”. Investigative Ophthalmology \& Visual Science 50/9 (2009) 4103-4109.

Luftig R. L. \& Muthert D. (2005). "Patterns of Employment and Independent Living of Adult Graduates with Learning Disabilities and Mental Retardation of an Inclusionary High School Vocational Program”. Research in Developmental Disabilities 26/4 (2005) 317-25.

Moreno J. L. (1939). "Psychodramatic Shock Tharapy. A Sociometrie Approach to the Problem of Mental Disorders”. Sociometry 2/1 (1939)1-30.

Özbaş A. (2014). Psikodrama Temelli Psikolojik Güçlendirme Programının Onkoloji Hemşirelerinin Güçlenme Algıları ve Tükenmişlik Düzeyleri Üzerine Etkisi. Yayımlanmamış Doktora Tezi. Erciyes Üniversitesi, Kayseri 2014.

Özbek A. \& Leutz G. (1987). Psikodrama Grup Psikoterapisinde Sahnesel Etkileşim. Ankara 1987.

Öztürk M. (2011). Türkiye’de Engelli Gerçeği. İstanbul 2011.

Öztürk M. O. (2001). Ruh Sağlı̆̆l ve Bozuklukları. Ankara 2001.

Öztürk O. (2004). Ruh Sağlı̆̆ ve Bozuklukları. Ankara 2004.

Parkan M. (2015). Şiddet Gören Kadınlarda Sosyal Destek ve Psikodrama’nın Pozitif Negatif Duygu Durumlarına ve Yaşam Doyumlarına Etkileri. Yayımlanmamış Yüksek Lisans Tezi. Haliç Üniversitesi, İstanbul 2015.

Rees G., Fenwick E., Keeffe J. E., Mellor D. \& Lamoureux E. L. (2009). "Detection of Depression in Patients with Low Vision”. Optometry and Vision Science 86/12 (2009) 948-954.

Rees G., Xie J., Holloway E. E., Sturrock B. A., Fenwick E., Keeffe J. E. \& Lamoureux E. (2013). "Identifying Distinct Risk Factors for Vision-Specific Distress And Depressive Symptoms in People with Vision İmpairment". Invest Ophthalmol Vision Science 54/12 (2013) 7431-7438.

Schützenberger-Ancelin A. (1995). Psikodrama: Yöntemlerin Bir Özet Sunumu. Ankara Grup Psikoterapileri Derneği Yayını No: 4. Ankara 1995.

Senra H., Barbosa F., Ferreira P., Vieira C., Perrin P., Rogers H., Rivera D. \& Leal I. (2015). "Psychologic Adjustment to İreversible Vision Loss in Adults: a Systematic Review". Ophthalmology 122/4 (2015) 851-861.

Shulman, L. (2016). The Skills of Helping Individuals, Families, Groups, and Communities (8 ${ }^{\text {th }}$ ed.). Boston 2016.

Somov P. G. (2008). “A Psychodrama Group for Substance use Relapse Prevention Training”. Arts Psychotherapy 35/2 (2008) 151-61.

Sütçügil L. \& Özmenler N. (2007). “Majör Depresyonda Psikososyal Müdahaleler”. Türkiye Klinikleri Dahili Tıp Bilimleri Dergisi 3/47 (2007) 46-50.

Şarlak D. \& Öztürk E. (2017). Psikodrama Temelli Bir Müdahale Programının Hafif Düzey Depresyonu Olan Üniversite Öğrencilerinin Umutsuzluk ve İntihar Ĕ̆gilim Düzeyleri Üzerine Etkisi. İstanbul. Yayımlanmamış Doktora Tezi. İstanbul Arel Üniversitesi, İstanbul 2017.

Şener Ö. (2018). Duygu Ahrazlığı (Aleksitimi) Yaşayan Üniversite Öğrencilerinin Duygu Ifadeleri ve Spontanlıkları Üzerine Psikodramanın Etkisi. Yayımlanmamış Doktora Tezi. İstanbul ÜniversitesiCerrahpaşa, İstanbul 2018.

Taylor S. (1999). Health, Illness and Medicine Sociology: Issues and Debates. London 1999.

Tournier M., Moride Y., Ducruet T., Moshyk A. \& Rochon S. (2008). "Depression and Mortality in the Visually-İmpaired, Community-Dwelling, Elderly Population of Quebec”. Acta Ophthalmologica 86/2 (2008) 196-201.

Türkiye İstatistik Kurumu (2013b). Türkiye Sağlık Araştırması Mikro Veri Seti 2012. Ankara 2013.

Türkiye İstatistik Kurumu. (2013a). Sağlık Araştırması 2012. Ankara 2013.

Watson D., Clark L. A. \& Tellegen A. (1988). "Development and Validation of Brief Measures of Positive and Negative Affect: The PANAS Scale”. Journal of Personality and Social Psychology 54/6 (1988) 1063-1070. 